\title{
Water control in South Asia: an introduction
}

\author{
Aaron Mulvany
}

Published online: 7 June 2014

(C) Springer Science+Business Media Dordrecht 2014

Water control in South Asia has long been dominated by the colonial imagination. To be sure, post-Independence India was defined as much by Nehruvian development politics as by anything else; one need but watch the opening scenes of Mehboob Khan's 1957 film Mother India to see just how deeply the idea of development had penetrated the popular imagination. But Nehruvian progress was rooted in the quantifiable: kilowatts of power generation, kilometers of rail, cubic meters of water flow-through. And this quantification of development was rooted very firmly in the colonial legacy of India. The ideology of empire demanded a 'scientific' approach to knowledge that valued "accuracy over intimacy [and] instruments over informants" (Mitchell 2009, p. 153). Local knowledge situated within a particular socio-environmental context gained and passed down over some undetermined passage of time-what James C. Scott (1998) termed mētis-was a little suspect at the very least. Any such knowledge not given by informants "of uncommon genius and knowledge" or "much superior to those with whom one usually meets in India" would be deemed wholly unreliable, and even the best such informants required verification (Edney 1999, pp. 81-82).

This paradigm has been slow to change despite the often savage critiques of development that have appeared since the 1980s. Why, James Ferguson (1990) would have us ask, does the discourse of 'development' seemingly and so often exclude both academic discourse and common sense? That the development paradigm has been traditionally not just rooted in but rooted to colonial ideas of progress should be our first clue. Though never expressed so blatantly, the paradigm of progress in the colonies more closely resembled 'trickle down' than it ever did 'build up.' As far as the British were concerned, real knowledge — about a people, about a place, about a process-came from the outside and only insofar as was deemed needful. This same lantern was used to cast light on water resource development in the years following the decolonization of South Asia.

A. Mulvany $(\bowtie)$

Department of Social Development and Policy, Habib University, Karachi, Pakistan

e-mail: aaron.mulvany@ahss.habib.edu.pk 
Over the last two decades especially, development-writ-large in South Asia has been slowly coming to re-evaluate the tradition-modernity binary that so dominated the colonial administration of the region. But there remains a decided lag in thinking about water and water management. As recently as 2012 the Government of India's Ministry of Water Resources released a Draft National Water Policy that stressed the public's general ignorance of the "economic value of water" (p. 1) and suggested that "water should increasingly be subjected to allocation and pricing on economic principles" (p. 6). This is quite a modern construction, suggesting even obliquely the privatization of what has traditionally been viewed as a resources of the commons, but its economic rationale is decidedly, well, colonial. And while the draft allowed that "the pre-emptive and high priority uses of water for sustaining life and ecosystem" (p. 6) were a national priority, the failure to define water as a fundamental right for all coupled with the perceived attempt to federalize what has traditionally been state-level authority stoked fears of the wholesale privatization of water in India. In the end, the provision of "pricing on economic principles" was removed from the final draft, but the anxieties about water allocation remain.

Modernity and its attending values of objectivity, legibility, rationality, and economic growth - the cri de coeur of development both colonial and contemporary-have in the decades following the Partition of India, as in the rest of the decolonized world, resulted in the de facto marginalization of traditional strategies of resource husbandry. A number of voices warn us to be wary of the divide between the pre-modern and the modern (e.g. Agarwal and Narain 1997; Harding 2008; Shah 2012), that modern science should only be considered as one way of knowing the world. But Shah in particular reminds us that 'premodern' strategies of environmental management, including water management, were not necessarily any more thoughtful or any less environmentally damaging than modern projects. And neither, as Mulvany demonstrates in this volume, are 'modern' strategies necessarily any more rational. The articles presented here all touch on this trope-local knowledge versus international expertise-from a variety of perspectives. One assumption that underlies all of these articles is the careful positioning of the notion of 'expertise' in ways that do not privilege external or international knowledge over local practice, or progress over tradition.

This volume arises out of a panel on water control in 19th and 20th century Asia organized by Philip C. Brown (Department of History, The Ohio State University) and held at the 2012 Society for the History of Technology annual meeting in Copenhagen. It is in many ways representative of the ways in which the newest generation of South Asia scholars is thinking and writing about water and water control in the modern subcontinent, and of the shared body of critique that begins with Scott and Ferguson and includes the work of writers like David Mosse (2003, 2005), Rohan D'Souza (2006), and Arun Agarwal (1995, 2002), among others, from which they draw.

Aaron Mulvany opens the volume with an unconventional discussion of contemporary flood policy in the former territories of French India. Drawing from the work of folklorists Gary Alan Fine and Barry O'Neill (2010), he uses the concept of the "policy legend" to examine how popularly held ideas about contemporary Puducherry's colonial legacy have shaped official discourse about flood and flood vulnerability in the region. Following their almost total defeat in India by the British-first at Wandiwash in 1760, then Pondicherry the following year-the tight circumscription of continental influence in the subcontinent caused the French administration to turn much of its attention inwards. While typically only the earliest British irrigation interventions were aimed at restoring existing irrigation works (Sharma 2008), from the nineteenth century onwards the French administration at Pondicherry focused a great deal of effort on restoring and later expanding existing 
waterworks, both the pre-colonial irrigation networks and the French works that had been repeatedly damaged during decades of conflict with the British. This undeniable historical legacy has generated a set of beliefs about the purpose and efficacy of French waterworks that circulates freely among officials in the contemporary administration. These beliefs very definitively shape the perception of both the risk and the experience of flood. These perceptions, in turn, have had direct effects on the ways in which strategies for the mitigation of future flooding have been developed.

Dan Haines' article examines David E. Lilienthal's involvement in the mid-century dispute between India and Pakistan over the Indus basin. Haines argues that Lilienthal deployed a discourse of technocratic internationalism in an effort to obscure-if not entirely negate-political factors that arose from the Partition of Pakistan and India in 1947. Lilienthal proposed the joint development of the water resources of the entire Indus basin (with the notable exception of the Kabul River), appealing to the shared hydrological expertise of local engineers on both sides of the dispute. Haines reads Lilienthal's intervention into the dispute as a representational exercise meant to discursively construct a depoliticized space in which development of the Indus basin could occur. By jumping scale from nationalist claims on sovereign water resources to internationalist claims of shared interest in the overall health of a 'natural' hydrological phenomenon, Lilienthal hoped to foster such a space. While ultimately unsuccessful in encouraging the principle of fully apolitical cross-border cooperation, Lilienthal's work was instrumental in widening the scope of the debate to include the whole of the Indus basin as a "natural" object of cooperative development, a shift that ultimately enabled the World Bank's intercession and mediation of the 1960 Indus Waters Treaty.

Returning focus entirely to India, Ramya Swayamprakash continues with the thread of development anti-politics and explores the ways in which the India's hydraulic bureaucracy came to conceptualize, discuss, and justify the technological interventions demanded by Nehruvian development politics. She begins by reminding us that technologically 'improving' India's rivers became a ubiquitous, all-India narrative. Expanding on a point touched upon by Haines, she shows how this discourse was used to encourage the growth of an indigenous cadre of apolitical engineering experts with the stated intention of developing regionally exportable hydrological expertise as a counterbalance to the influx of advisors from the West. These policies were meant not just to develop the industrial economy of the nation but its knowledge economy as well. Internally, efforts to interlink India's major waterways across the length and breadth of the country was as much about building the economy as it was a rational exercise to define, justify, and unify the new nation. Externally, by encouraging the growth of indigenous engineering expertise and an attending regional narrative about water resources, India hoped to promote its standing across the region. Swayamprakash draws from the words of engineers themselves in order to show how India sought through its development projects to represent itself as a unified, sovereign, regional leader.

Debojyoti Das narrows the discussion from the all-India context to focus on Majuli Island. He shifts our attention from the rationalized, Western-influenced discourse of development expertise and economic growth to the importance of recognizing indigenous knowledge in understanding and shaping water management on the Brahmaputra River. Outlining a range of existing ideologies and approaches for understanding the environment at large, Das points a way towards a new conceptual framework for ecological intervention while warning that the "complex regime of rivers cannot be solely understood scientifically." He convincingly argues that the statist "command and control" policies that have dominated discussions of the Brahmaputra River since the 1950 Assam earthquake-an 
earthquake that that significantly shifted its watercourse-are rooted in a fundamentally flawed understanding of the river's ecology and development potential. By deploying a "crisis" narrative, the Government of India has been able to justify numerous interventions in the region-long the center of Assam's tea, and more recently oil, economy-but these have only served to aggravate the island's ecological stressors. He suggests that strategies of resilience based on local understandings of flood and flood risk offer better alternatives to the still dominant "techno-managerial" discourses that have divorced resource management from indigenous experience.

The articles in this volume are intended to give a sense of some of the most current thinking about water in the South Asian context. Interventions like those made by Das and Mulvany are increasingly important for problematizing the paradigms of neo-colonial rationality that still dominate discourses of water resource management in the region. Haines and Swayamprakash remind us that, as the threats of global 'water wars' and water privatization grow, depoliticized spaces for regional debates about water resource development and allocation have been already imagined and attempted. Read individually, each of these papers has something interesting to say about post-colonial water management regimes in South Asia. Read together, however, they reveal a fascinating picture of the Indo-Pak core of the subcontinent in the last half of the twentieth century.

\section{References}

Agarwal A (1995) Dismantling the divide between indigenous and scientific knowledge. Dev Change 26(3):413-439

Agarwal A, Narain S (eds) (1997) Dying wisdom: rise fall and potential of India's traditional water harvesting systems. Centre for Science and Environment, New Delhi

Agrawal A (2002) Indigenous knowledge and the politics of classification. Int Soc Sci J 54(173):287-297. doi:10.1111/1468-2451.00382

D'Souza R (2006) Drowned and dammed: colonial capitalism and flood control in eastern India (1803-1946). Oxford University Press, New Delhi

Edney MH (1999) Mapping and empire: the geographical construction of British India, 1765-1843. University of Chicago Press, Chicago

Ferguson J (1990) The anti-politics machine: "Development," depoliticization, and bureaucratic power in Lesotho. Cambridge University Press, Cambridge

Fine GA, O'Neill B (2010) Policy legends and folklists: traditional beliefs in the public sphere. J Am Folklore 123(488):150-178. doi:10.1353/jaf.0.0133

Harding S (2008) Science from below: Feminisms, postcolonialities, and modernities. Duke University Press, London

Ministry of Water Resources (2012) Draft national water policy as recommended by national water board in its 14th meeting held on 7th June, 2012. Govt. of India, http://mowr.gov.in/writereaddata/linkimages/ draftnwp2012_english9353289094.pdf. Accessed 21 May 2014

Mitchell L (2009) Knowing the Deccan: enquiries, points, and poets in the construction of knowledge and power in early-nineteenth-century Southern India. In: Trautmann TR (ed) The Madras School of Orientalism: producing Knowledge in Colonial South India. Oxford University Press, Oxford

Mosse D (2003) The Rule of water: statecraft, ecology and collective action in South India. Oxford University Press, New Delhi

Mosse D (2005) Cultivating development: an ethnography of aid policy and practice. Pluto Press, London

Scott JC (1998) Seeing like a state: how certain schemes to improve the human condition have failed. Yale University Press, New Haven

Shah E (2012) "Seeing like a subaltern-historical ethnography of pre-modern and modern tank irrigation technology in Karnataka. India. Water Altern 5(2):507-538

Sharma S (2008) Elusive rains and parched lands: situating droughts in colonial India. In: Jairath J, Ballabh V (eds) Droughts and integrated water resource management in South Asia: Issues, alternatives, and futures, Water in South Asia, vol 2. Sage, Los Angeles, pp 70-97 